\title{
PENGARUH KOMUNIKASI INTERPERSONAL DAN KEPERCAYAAN TERHADAP LOYALITAS GURU SMK SWASTA DI KECAMATAN KEMAYORAN JAKARTA PUSAT
}

\author{
Gilang Kartika Hanum \\ Dosen STMIK Raharja \\ Jl. Jendral Sudirman No. 40, Modern Cikokol, Tangerang \\ E-mail : gilanghanum@raharja.info
}

\begin{abstract}
ABSTRAK
Penelitian ini bertujuan mengetahui pengaruh (1) komunikasi interpersonal, (2) kepercayaan, (3) loyalitas guru SMK di Kemayoran. Data dalam penelitian ini menggunakan teknik analisis jalur. Penelitian dengan sampel 95 guru di lima SMK dengan metode Formula Slovin. Hasil penelitian berdasarkan variable yang diteliti. Pertama terdapat pengaruh positif antara komunikasi interpersonal dan loyalitas guru. Kedua, terdapat pengaruh positif antara kepercayaan dan loyalitas guru. Ketiga terdapat pengaruh positif antara komunikasi interpersonal dan kepercayaan guru di $S M K$.

Kata kunci : Komunikasi interpersonal, kepercayaan, dan loyalitas
\end{abstract}

\begin{abstract}
This research is aimed to investigate the effect of (1) interpersonal communication, (2) trust, (3) loyalty of teacher the vocational high school in Kemayoran.

In the data analysis, this research uses causal survey method by using Path Analysis Technique. This study uses the sample from 95 teachers in five vocational high school in Kemayoran who are selected by using Slovin formula.

The result of the study reveals that: First, there is a positive effect between interpersonal communication and teacher loyalty to the school. Second, there is a positive effect also between trust and teacher loyalty to the school.Third there is a positive effect between interpersonal communication and teacher trust to the school.

Keywords: interpersonal communication, trust, and loyalty.
\end{abstract}

\section{PENDAHULUAN}

Guru sebagai pengajar dituntut bertanggung jawab dan konsekuensi pada tugas utamanya seperti dalam proses belajar mengajar, memiliki strategi kognitif yang dapat menumbuhkan kemampuan mengatur, dan mengelola hubungan yang baik antar sesama guru dan kepala sekolah. Guru juga harus mampu menjalin interaksi dan kerja sama dengan sesama guru lainnya. Jika guru merasa nyaman di lingkungan pekerjaannya dengan tingkat kepuasan yang tinggi maka loyalitasnya pada profesinya juga tinggi. Bentuk optimalisasi pengajaran dan keleluasaan pergaulan antar sesama guru menggambarkan loyalitas guru dalam menjalankan tugasnya. Loyalitas guru pada profesinya akan membuat guru menjalankan tugasnya dengan sebaik mungkin sesuai dengan standar profesi guru.

Salah satu faktor yang mempengaruhi loyalitas guru adalah komunikasi interpersonal. Peranan komunikasi tidak saja sebagai sarana atau alat bagi Kepala Sekolah menyampaikan 
informasi tentang suatu kebijakan, tetapi juga sebagai sarana memadukan aktivitas-aktivitas secara terorganisasi dalam mewujudkan kerjasama. Bahwa suatu organisasi tidak dapat melaksanakan fungsinya tanpa adanya komunikasi dan bahkan lebih dari itu organisasi tidak dapat berdiri tanpa komunikasi. Komunikasi sesama guru termasuk kompetensi yang wajib dimiliki oleh guru. Sikap ini, dapat diwujudkan di dalam maupun di luar sekolah. Di dalam sekolah, sesama guru, harus membina hubungan yang harmonis,kasih-mengasihi, terbuka dan lain sebagainya. Di luar sekolah, jika ada teman sejawat yang sedang sakit, guru lainnya menjenguk atau memberikan bantuan materi dan sebagainya.

Guru juga harus membina hubungan yang baik dan akrab dengan orang tua siswa maupun masyarakat sekitar. Hubungan yang seperti ini dapat memperlancar pendidikan di sekolah. Sehingga dengan informasi yang diperoleh, dapat guru jadikan sebagai pertimbangan dalam pengajaran maupun bimbingan. Jika komunikasi tidak dikembangkan maka bisa terjadi kesalah pahaman dan kurang jelasnya informasi yang diterima guru, kesulitan melaksanakan perintah dari kepala sekolah, kesalah pahaman di antara para guru sehingga terjadi rasa tidak mempercayai satu sama lain berdampak pada turunnya sikap tanggung jawab terhadap profesi guru.

Selain komunikasi interpersonal hal lain yang mempengaruhi loyalitas guru SMK swasta adalah kepercayaan. Kepercayaan menempati posisi penting dalam sebuah organisasi. Apabila tidak saling memiliki rasa percaya terhadap rekan kerja, maka akan memudar dorongan untuk bekerja sama dengan baik, dan tidak menghargai pendapat orang. Beberapa fakta yang dipaparkan di atas mengindikasikan bahwa loyalitas guru masih dipertanyakan. Dari beberapa faktor yang mempengaruhi loyalitas guru, dibatasi hanya pada pengaruh komunikasi interpersonal dan kepercayaan terhadap loyalitas guru SMK Swasta kecamatan Kemayoran Jakarta Pusat.

\section{Loyalitas}

Menurut Kreitner dan kinicki (2010:24) menjelaskan Loyalty: promises, contracts, and commitment should be honored. Loyalty include fidelity, promise keeping, keeping the public trust, good citizennship, exellent in quality of work, reliability, commitment, and honoring law, rules and policies. Loyalitas: janji, kontrak, dan komitmen harus dihargai. Loyalitas termasuk kesetiaan, berjanji menjaga, menjaga kepercayaan publik, warga negara yang baik, sempurna dalam kualitas kerja, keandalan, komitmen, dan menghormati hukum, peraturan dan kebijakan.Menurut Robbins (2007:102), "another important judgment that managers make about employees is whether or not they are loyal to the organization." Loyalitas merupakanpenilaian penting lainnya yang dibuat manajer tentang karyawan apakah mereka loyal atau tidak kepada organisasi. Griffin (2002:2) mendefinisikan loyalitas adalah "loyalty is defined as non random purchase expressed over time by some decision making unit." Bahwa loyalitas ditunjukkan pada suatu perilaku pembelian rutin yang didasarkan pada unit pengambilan keputusan. Maksudnya orang yang memiliki loyalitas tinggi adalah seseorang yang melakukan sesuatu secara berulang didasakan keputusannya karena adanya kepuasan 
dalam dirinya.Koetler (2003:97) menyatakan bahwa, "Loyalty is an old-fashioned word describing being deeply commited to one's country, family or friends". Loyalitas adalah sebuah bentuk lama yang menggambarkan kepercayaan mendalam terhadap suatu negara, keluarga atau teman. Mowday, Porter, dan Steers (1982:185) mendefinisikan loyalitas organisasi sebagai, "defined isthe relative stregth on an individual's identification with and involement in a particular organization". Definisi tersebut menunjukan bahwa loyalitas organisasi memiliki arti yang lebih dari sekedar loyalitas pasif, namun melibatkan hubungan aktif dan keinginan karyawan memberikan kontribusi yang berarti ada organisasinya. Aspekaspek loyalitas menurut Siswanto (2006:235) yang terdapat pada individu menitikberatkan pada pelaksanaan kerja yaitu :Taat peraturan, tanggung jawab, dan sikap kerja. Dari uraian di atas disintesiskan adalah kesetiaan, pengabdian, kepercayaan yang diberikan atau ditujukan individu kepada seseorang atau lembaga yang didalamnya terdapat rasa cinta dan tanggung jawab untuk berusaha memberikan pelayanan dan perilaku yang terbaik dengan indikator 1) taat pada peraturan, 2) tanggung jawab dan 3) sikap kerja.

\section{Komunikasi Interpersonal}

Devito (2009:112) menyatakan bahwa, "Communication transpires in many characteristics, including intrapersonal, interpersonal, group, organisational and mass communication”. Komunikasi berlangsung dalam banyak karakteristik meliputi komunikasi intrapersonal, komunikasi interpersonal, komunikasi kelompok, komunikasi organisasi dan komunikasi massa.Menurut Steven L. McShane, Mary Ann Von Glinow (2010:270), "communication the process by which information is transmitted and understood between two or more people". Komunikasi proses informasi ditransmisikan dan dipahami antara dua atau lebih orang.

Dalam suatu organisasi, komunikasi mengalir dari individu ke individu dalam bentuk tatap muka atau kelompok. Gibson (2009:20) menyatakan, "Interpersonal communication is communications that flow between face to face or group situation." Menurut Robbins dan Coulter (2012:405) "communication between two or more people". Komunikasi terjalin antara dua orang atau lebih.Menurut Luthans (2013:340),"in interpersonal communication, the major emphasis is on transferring information from one person to another". Komunikasi interpersonal itu transfer informasi dari satu orang ke orang lain. Robbins dan Judge (2013:340) mengatakan bahwa " interpersonal communication is how do group members transfer meaning between and among each other? They essentially rely on oral, written, and nonverbal communication." Komunikasi interpersonal adalah bagaimana anggota kelompok mengirim pesan antara dua orang atau antara satu dan lainnya. Mereka pada dasarnya berkomunikasi dengan bahasa lisan, tertulis dan bahasa non verbal. Dari beberapa teori dapat disintesiskan bahwa komunikasi interpersonal adalah proses penyampaian pesan dan penerimaan pesan baik secara langsung/tatap muka maupun tidak langsung secara verbal maupun nonverbal oleh individu terhadap orang lain. Dengan indikator : (1) transfer informasi dari satu pihak ke pihak lain, (2) berbagi informasi antara dua orang atau lebih, (3) berlangsung dalam situasi tatap muka, (4) dilakukan untuk mendapatkan umpan balik. 


\section{Kepercayaan}

Robbins dan Timothy A. Judge (2013:387) menyatakan bahwa kepercayaan dapat dimaknai sebagai " a positive expectation that another will not through words, action, or decision act opportuniscally". Kepercayaan merupakan suatu harapan positif bahwa yang lain tidak akan mengambil kesempatan melalui kata-kata, tindakan atau keputusan.Menurut Colquitt, LePine, dan Wesson (2009:219) adalah "as the willingness to be vulnareble to an authority based on positive expectations about the authority's actions and intension". Dimaknai sebagai kesediaan untuk menggantungkan diri pada suatu otoritas berdasarkan harapan yang positif akan tindakan dan perhatian otoritas.Menurut Kretner/Kinicki (2010\{:319) “Reciprocal faith in other's intentions and behavior”. Kepercayaan adalah memberi dan menerima kepercayaan kepada orang lain dengan maksud berperilaku baik.Menurut McShane dan Von Glinow (2010:251) "Trust refers to positive expectations one person has toward another person in situations involving risk". Kepercayaan adalah suatu keadaan psikologis yang terdiri dari niat untuk menerima kelemahan berdasarkan harapan positif dari niat atau perilaku orang lain. Kepercayaan berarti keyakinan ditempatkan pada orang lain atau kelompok. Ini juga merupakan aktivitas timbal balik. Untuk menerima kepercayaan, harus menunjukkan kepercayaan. Suzanne (2009:33) membagi kepercayaan ke dalam lima dimensi, "research has identified five dimensions that make up the concept of trust: (1) integrity, (2) competency, (3) consistency, (4) loyalty, (5) opennes. Integritas, Kompetensi, Konsistensi, Kesetiaan, Keterbukaan, Berdasarkan kajian teori tersebut di atas, maka dapat disintesiskan bahwa kepercayaan adalah keyakinan dan harapan positif individu terhadap orang lain dengan indikator, yaitu: (1) integritas (integrity), (2) kompetensi (competency), (3) konsistensi (consistency), (4) kesetiaan (loyalty) dan (5) keterbukaan (openness).

\section{METODE}

Penelitian ini bertujuan untuk menguji pengaruh langsung; (1) Komunikasi Interpersonal terhadap Loyalitas, (2) Kepercayaan terhadap Loyalitas, dan (3) Komunikasi Interpersonal terhadap Kepercayaan. Penelitian menggunakan metode survey dengan pendekatan teknik analisis jalur. Penelitian dilaksanakan di SMK Swasta kecamatan Kemayoran Jakarta Pusat. Populasi terjangkau penelitian ini sejumlah 125 guru. Sampel penelitian sebayak 95 orang. Analisa data untuk pengujian hipotesis akan dilakukan dengan menggunakan teknik analisis jalur, yaitu teknik yang diterapkan untuk menjelaskan pengaruh antara variabel-variabel penelitian. Sebelum dilaksanakan analisis jalur, uji signifikan regresi dan uji linearitas regresi sebagai prasyarat uji statistik dilakukan pengujian penormalan data dari masing-masing variabel penelitian dengan Uji-Liliefors, Statistik inferensial digunakan untuk menguji hipotesis tentang pengaruh antar variabel dengan menggunakan teknik analisis jalur. 


\section{HASIL DAN PEMBAHASAN}

\section{Pengaruh Komunikasi Interpersonal terhadap Loyalitas}

Dari hasil pengujian hipotesis pertama dapat disimpulkan bahwa terdapat pengaruh langsung positif komunikasi interpersonal terhadap loyalitas dengan nilai koefisien korelasi sebesar 0,404 dan nilai koefisien jalur sebesar 0,350. Ini memberikan makna komunikasi interpersonal berpengaruh langsung terhadap loyalitas. Hasil penelitian ini senada dengan pendapat beberapa ahli diantaranya adalah Beebe dan Raymond (2002:212) menyatakan "Interpersonal communication is conceptualized as more about the content and character of exchange with respect to communication to maintain relationship which seems to have strong influence on customer loyalty".Komunikasi interpersonal adalah karakter komunikasi yang menghargai menjadi pokok utama terjalinnya hubungan dan berpengaruh kuat terhadap loyalitas. Michael Toedt (2014:235) menyatakan : "communication plays an important role for the creation of loyalty respectively for keeping existing customers loyal could be confirmed". Komunikasi memegang peranan penting bagi terciptanya loyalitas dapat dipastikan berguna untuk menjaga keeratan.Dari uraian di atas dapat dilihat pengaruh antara kedua variabel yakni komunikasi interpersonal yaitu interaksi pertukaran makna antara seseorang dengan orang lain dalam bentuk verbal maupun nonverbal yang dilakukan secara timbal balik. Komunikasi memiliki aspek-aspek transfer informasi dan berbagi informasi, berlangsung saling tatap muka dan dilakukan untuk mendapatkan umpan balik. Dengan adanya komunikasi maka akan terjadi interaksi informasi dan pemikiran yang dapat disampaikan orang lain. Hal demikian apabila proses penyampaian informasi dan komunikasi dengan rekan yang lain berjalan baik, maka akan mendukung tingginya loyalitas. Berdasarkan uraian diatas jelas bahwa komunikasi interpersonal berpengaruh positif terhadap loyalitas guru.

\section{Pengaruh Kepercayaan terhadap Loyalitas}

Dari hasil pengujian hipotesis kedua dapat disimpukan bahwa terdapat pengaruh langsung positif kepercayaan terhadap loyalitas dengan nilai koefisien korelasi sebesar 0,291 dan nilai koefisien jalur sebesar 0,194. Ini memberikan makna kepercayaan berpengaruh langsung terhadap loyalitas. Hasil penelitian ini senada dengan pendapat ahli, menurut Ibanez dkk (2006:633) "The impact of the trust on loyalty becomes exclusively relevant and important in case of decision taken for changing the brand due to high level of perceived risk and obscurity". Dampak dari kepercayaan terhadap loyalitas menjadi pokok yang relevan dan penting dalam hal mengambil keputusan untuk mengubah pandangan. Zeffane et all (2011) menyatakan: "that trust is still at the centre of the equation and that it is through trust that feelings of loyalty and commitment are formed". Kepercayaan menjadi pokok utama karena melalui kepercayaan bisa membentuk loyalitas dan komitmen. Kepercayaan terbukti dapat meningkatkan loyalitas. Loyalitas dapat dilihat melalui kelangsungan interaksi atau transaksi. Dijelaskan bahwa guru dapat menunjukan loyalitasnya. Guru dalam hal ini dikategorikan sebagai karyawan yang melaksanakan rutinitas tugas dan pekerjaan serta sering berinteraksi maka guru memiliki kepercayaan dan merasa dipercayai oleh organisasi. Berdasarkan uraian diatas menunjukan bahwa kepercayaan berpengaruh positif terhadap loyalitas. 


\section{Pengaruh Komunikasi Interpersonal terhadap Kepercayaan}

Dari hasil pengujian hipotesis ketiga dapat disimpulkan bahwa terdapat pengaruh langsung positif komunikasi interpersonal terhadap kepercayaan dengan nilai koefisien korelasi sebesar 0,276 dan nilai koefisien jalur sebesar 0,276. Ini memberikan komunikasi interpersonal berpengaruh langsung terhadap kepercayaan.Hasil penelitian ini senada dengan pendapat beberapa ahli di antaranya, Thomas dan Trevino (1993:779) berpendapat "concerning proactive information processing to suggest that communications can be used to boost trust". Proses informasi yang proaktif ditunjukan bahwa komunikasi dapat meningkatkan kepercayaan. Menurut Rachid Zeffane (2011:79):The quality and frequency of communication goes a long way toward creating an atmosphere of trust. Therefore, efective communication is an essential ingredient for trust between employees as well as trust between managers and employee. Komunikasi yang baik dengan frekuensi sering akan membentuk atmosfir kepercayaan. Dijelaskan bahwa berjalannya komunikasi yang baik dan lancar dari kepala sekolah bahkan sesama guru mendorong rasa saling mempercayai dan terbuka.

\section{PENUTUP}

\section{Kesimpulan}

Berdasarkan hasil pengujian hipotesis dan pembahasan yang telah dikemukakan diperoleh kesimpulan penelitian sebagai berikut: (1) Komunikasi Interpersonal berpengaruh langsung positif terhadap Loyalitas. Artinya, jika Komunikasi Interpersonal yang baik maka menciptakan Loyalitas. (2) Kepercayaan berpengaruh langsung positif terhadap Loyalitas. Artinya, jika kepercayaan yang tinggi maka mendukung tingginya Loyalitas. (3) Komunikasi Interpersonal berpengaruh langsung terhadap Kepercayaan. Hal ini menunjukkan bahwa jika komunikasi makin baik maka mendorong tingginya Kepercayaan.

\section{Saran}

Berdasarkan kesimpulan penelitian dapat dirumuskan beberapa saran: (1) Upaya perbaikan komunikasi interpersonal untuk membangun loyalitas adalah melakukan pembiasaan sikap saling menghargai dan berinteraksi secara jujur untuk mewujudkan kekompakan dan kerjasama yang baik. (2) Upaya perbaikan kepercayaan untuk menciptakan loyalitas dapat dilakukan dengan cara mengarahkan pada sikap positif dengan saling terbuka dan melaksanakan pengembangan karir bagi guru, supaya guru merasa aman dan nyaman dengan kepastian karirnya disekolah. (3) Upaya perbaikan komunikasi interpersonal untuk meningkatkan kepercayaan yaitu bersikap konsisten, rasa tanggung jawab dan ketaatan. 


\section{DAFTAR PUSTAKA}

[1] Beebe, Steven A., Susan J. Beebe and Mark V. Redmond. Interpersonal Communication. Boston: Allyn and Bacon. 2002.

[2] Benesbordi, Ali,Nayeb Ali Rahmati,M. Goodarzi and Masume Heidary. The Effect of Interpersonal Relationships with Customers`Loyalty in Soccer Schools in Tehran-Iran, International Journal of Academic Research in Business and Social Sciences, Vol. 2, No. 1, 2012.

[3] Colquitt, Jason A., Jeffry A. Lepine and Michael J. Wesson. Organizational Behavior: Improving Performance and Commitment in The Workplace. New York: McGraw-Hill Irwin, 2009.

[4] Devito, Joseph A.The Interpersonal Communication. Fifth Edition. New York: Harper Collins College Publisher, 2009.

[5] De Janasz. C. Suzanne, Karen O. Dowd, and Beth Z. Schneider, Interpersonal Skills in Organization. New York : McGraw-Hill Inc, 2009.

[6] De Ridder, Jan A. Organizational communication and supportive employees. Human Resource Management Journal, 14 (3), 20-30, 2006.

[7] Gefen, D dan Straub, D.W. Customer trust in b2c e-commerce and the importance of social presence : experiments in e-products and e-services, The International Journal of Management Sciences, Vol.32 No.6, pp.407-424. 2004.

[8] Gibson, James L, et al. Organization: Behavior, Structure, Process. New York: McGrawHill/Irwin, 2009.

[9] Griffin, Jill. Customer Loyalty How to Earn it, How to Keep It.Kentucky: McGraw Hill, 2002.

[10] Ivancevich, John M., Robert Konopaske, dan Michael T. Matteson. Organizational Behavior and Management $9^{\text {th }}$ edition. New York: McGraw-Hill, 2011.

[11] Knicki, Angelo., and Robert Kreitner. Organizational Behavior, Key Concepts, Skills \& Best Practices . New York: McGraw-Hill, 2010.

[12] Koetler, Philip. Marketing Insight from A to Z. New Jersey: John Wiley \& Sons, 2003.

[13] Kreitner, Robert and Angelo Kinicky. Organizational Behavior. New York: McGrawHill Irwin, 2010.

[14] Lee, Kuan-Yin, Hui-Ling Huang and Yin-Chiech Hsu, Trust, Satisfaction and Commitment- On Loyalty to International Retail Service Brands , Asia Pacific Management Journal. 2007

[15] Luthans, Fred. Organizational Behavior. 12 ${ }^{\text {th }}$ edition.New York: McGraw-Hill, 2011.

[16] McShane, Steven L, Mary Ann Von Glinow, Organizational Behavior. New York: McGraw-Hill, 2007.

[17] Porter, Mowday,R.T,„L.W, and Steers R.M. Employee Organization Linkage: The Psychology of Commitment, Absteism \& Turnover. NewYork: Academy Press, 1982.

[18] Robbins, Stephen P. dan Mary Coulter, Management. England: Pearson Education, 2012.

[19] Robbins, Stephen P. dan Timothy A. Judge, Organization Behavior. New Jersey : Pearson Education, Inc, 2011. 
[20] Siswanto, Manajemen Tenaga Kerja Indonesia. Revisi Ketiga. Jakarta : Bumi Aksara, 2006.

[21] Thomas, J.Bdan L.K Trevino. Information processing in strategic alliance building : Multiple case approach. Journal of Management Studies, vol.3 no.5, 1993.

[22] Toedt, Michael, A Model For Loyalty In The Context Costumer Relationship Marketing. European Scientific Journal. Vol.1, 2014. 